\title{
The Paleocene-Eocene carbon isotope excursion in higher plant organic matter: Differential fractionation of angiosperms and conifers in the Arctic
}

\author{
Stefan Schouten $^{\mathrm{a}, *}$, Martijn Woltering ${ }^{\mathrm{a}, 1}$, W. Irene C. Rijpstra ${ }^{\mathrm{a}}$, Appy Sluijs ${ }^{\mathrm{b}}$, \\ Henk Brinkhuis ${ }^{b}$, Jaap S. Sinninghe Damsté ${ }^{a, c}$ \\ a Royal Netherlands Institute for Sea Research, Department of Marine Biogeochemistry \& Toxicology, \\ PO Box 59, 1790 AB, Den Burg (Texel), The Netherlands \\ b Palaeoecology, Institute of Environmental Biology, Utrecht University, Laboratory of Palaeobotany and Palynology, \\ Budapestlaan 4, 3584 CD Utrecht, The Netherlands \\ ${ }^{\mathrm{c}}$ Department of Geochemistry, Utrecht University, Budapestlaan 4, 3584 CD Utrecht, The Netherlands
}

Received 25 January 2007; received in revised form 13 April 2007; accepted 13 April 2007

Available online 20 April 2007

Editor: H. Elderfield

\begin{abstract}
A study of upper Paleocene-lower Eocene (P-E) sediments deposited on the Lomonosov Ridge in the central Arctic Ocean reveals relatively high abundances of terrestrial biomarkers. These include dehydroabietane and simonellite derived from conifers (gymnosperms) and a tetra-aromatic triterpenoid derived from angiosperms. The relative percentage of the angiosperm biomarker of the summed angiosperm + conifer biomarkers was increased at the end of the Paleocene-Eocene thermal maximum (PETM), different when observed with pollen counts which showed a relative decrease in angiosperm pollen. Stable carbon isotopic analysis of these biomarkers shows that the negative carbon isotope excursion (CIE) during the PETM amounts to 3\% for both conifer biomarkers, dehydroabietane and simonellite, comparable to the magnitude of the CIE inferred from marine carbonates, but significantly lower than the $4.5 \%$ of the terrestrial $\mathrm{C}_{29} n$-alkane [M. Pagani, N. Pedentchouk, M. Huber, A. Sluijs, S. Schouten, H. Brinkhuis, J.S. Sinninghe Damsté, G.R. Dickens, and the IODP Expedition 302 Expedition Scientists (2006), Arctic's hydrology during global warming at the Paleocene-Eocene thermal maximum. Nature, 442, 671-675.], which is a compound sourced by both conifers and angiosperms. Conspicuously, the angiosperm-sourced aromatic triterpane shows a much larger CIE of 6\%o and suggests that angiosperms increased in their carbon isotopic fractionation during the PETM. Our results thus indicate that the $4.5 \%$ $\mathrm{C}_{29} n$-alkane CIE reported previously represents the average CIE of conifers and angiosperms at this site and suggest that the large and variable CIE observed in terrestrial records may be partly explained by the variable contributions of conifers and angiosperms. The differential response in isotopic fractionation of angiosperms and conifers points to different physiological responses of these vegetation types to the rise in temperature, humidity, and greenhouse gases during the PETM.
\end{abstract}

(C) 2007 Elsevier B.V. All rights reserved.

Keywords: Paleocene-Eocene; carbon isotopes; angiosperms; conifers

\footnotetext{
* Corresponding author.

E-mail address: schouten@nioz.nl (S. Schouten).

${ }^{1}$ Present address: Large Lakes Observatory, University of Minnesota Duluth, 10 University Drive, 109 RLB Duluth, MN 55812, USA.
} 


\section{Introduction}

The Paleocene-Eocene thermal maximum (PETM) is characterized by large global climatic changes. Proxy analysis suggests that global surface temperatures rose quasi-uniformly by $\sim 5^{\circ} \mathrm{C}$ at all latitudes [1-3], and locally by up to $8{ }^{\circ} \mathrm{C}[4-6]$, and that bottom water temperatures rose by as much as $5{ }^{\circ} \mathrm{C}$ [7]. Associated substantial changes included severe dissolution of deep sea carbonates [8], global proliferation of exotic plankton, such as the subtropical dinoflagellate Apectodinium (e.g [9-11]) and extinctions of benthic foraminifera [12]. On land, a strong increase in humidity was inferred in the Central United States of America [13] and the Arctic realm [14]. In addition, transient changes in vegetation composition were documented [2]. The large scale warming of the Earth also led to wide-spread mammal migration and perhaps evolution $[15,16,11]$.

The Paleocene-Eocene boundary is further characterized by a global geologically rapid prominent $(>2.5 \%$ ) negative stable Carbon Isotope Excursion (CIE), measured in marine and terrestrial sedimentary carbon $[4,17,5,14]$ which reflects a substantial and rapid input of ${ }^{13} \mathrm{C}$-depleted $\mathrm{CO}_{2}$ and/or $\mathrm{CH}_{4}$ into the oceanatmosphere system. Potential processes that could have led to such rapid release of ${ }^{13} \mathrm{C}$-depleted carbon include intrusion-forced injection of thermogenic methane [18], the dissociation of submarine methane-hydrates [19], large scale combustion of peat deposits [20] or desiccation of isolated marine sea ways leading to large scale oxidation of organic matter [21].

Because the mixing time of carbon within the global exogenic carbon pool is in the order of one to a few kyr, the magnitude of the CIE should in theory be equal in the atmosphere and in the ocean. The deep ocean comprises the largest reservoir of inorganic carbon and the magnitude of the CIE should be best measured in this realm. In benthic foraminiferal calcite from the most expanded deep marine carbonate-rich sedimentary successions the magnitude of the CIE is $\sim 2.5 \%$ (Table 1). However, due to the carbon injection, significant shoaling of the lysocline and the calcite compensation depth (CCD) occurred, resulting in a lack of carbonate sedimentation in most deep sea sections and chemical erosion of upper Paleocene carbonate material $[8,22]$. This has led to a brief hiatus near the onset of the CIE in most deep sea carbonate sections, though shallower sites should be less affected and provide a more complete record of the CIE [6]. The decrease in deep ocean $\mathrm{pH}$ and $\left[\mathrm{CO}_{3}^{2-}\right]$ likely resulted in a $0.5 \%$ dampening of the CIE measured in benthic foraminiferal calcite [13], and thus the CIE of atmospheric $\mathrm{CO}_{2}$ inferred from benthic foraminifera is $\sim 3 \%$. The CIE in surface dwelling planktonic foraminifera is often slightly larger, i.e. ca. $3-4 \%$ (Table 1 ). Potentially a $0.5 \%$ correction should also be applied for the CIE measured in planktonic foraminiferal calcite [13], but surface ocean records may also have been affected by local variations in productivity leading to additional depletions in ${ }^{13} \mathrm{C}$. Summarizing, based on marine calcite it is likely that the magnitude of the $\mathrm{CIE}$ of atmospheric $\mathrm{CO}_{2}$ is $\sim 3-3.5 \%$.

The magnitude in the CIE of organic carbon in marine sections is commonly larger and more variable (Table 2) which can be partly attributed to stratigraphic incompleteness of sections but also to changes in sources of organic matter, i.e. higher predominance of terrestrial over marine organic matter, and changes in isotopic fractionation due to changes in productivity (cf. [11]). The CIE on land is commonly of an even larger magnitude, i.e. 5-6\% in paleosol carbonates (Table 2). Bowen et al. [13] attributed this larger shift predominantly due to increasing fractionation in ${ }^{13} \mathrm{C}$ by plants due to increased humidity. Pagani et al. [14], however, also found a large CIE in terrestrially derived $n$-alkanes, ca. $4.5 \%$ in sediments from the Lomonosov Ridge in the Arctic Ocean. Since the environment from which these compounds were derived, continents surrounding the Arctic Ocean, was already humid prior to the CIE, the larger CIE could not easily be explained by strong increases in humidity and soil moisture [14]. Instead, they suggested that their excursion reflected the true CIE in atmospheric $\mathrm{CO}_{2}$, and that marine carbonates did not capture the CIE to its full extent. However, odd carbon numbered $n$-alkanes are produced by a large range of different vegetation types, specifically angiosperms and gymnosperms, with different isotopic compositions. Angiosperms are generally more ${ }^{13} \mathrm{C}$-depleted in biomass [23], resins [24] and $n$-alkanes [25] by up to $3 \%$ compared to that of gymnosperms. Hence, the larger magnitude of the terrestrial CIE as observed by Pagani et al. [14] is potentially associated by the shift in floral composition from a predominantly gymnosperm-based (pollen)flora to an angiosperm-dominated (pollen)flora as suggested by pollen analysis in the same Arctic Ocean sediment core [3].

To investigate this issue we examined the isotopic composition of aromatic diterpenoid biomarkers specific for conifers, the most important group of gymnosperms in temperate environments, and a tetra-aromatic triterpenoid biomarker specific for angiosperms in PETM sediments recovered from drilling of the Lomonosov Ridge where previously the large CIE was documented in terrestrial $n$-alkanes [14]. Our results show that the 
Table 1

Summary of reported magnitudes (rounded to $0.5 \%$ precision) of carbon isotope excursions in marine sections during the PETM

\begin{tabular}{|c|c|c|c|}
\hline Source & Location & Excursion (\%o vs VPDB) & Reference \\
\hline \multirow[t]{12}{*}{ Planktonic forams } & \multirow[t]{2}{*}{ Maud Rise, Weddell Sea } & 4.0 & Kennett and Stott [4] \\
\hline & & 4.0 & Thomas et al. [5] \\
\hline & Kerguelen Plateau, Indian Ocean & 3.5 & Lu and Keller [53] \\
\hline & Bay of Biscay, North Atlantic & 2.0 & Pardo et al. [54] \\
\hline & Alademilla section, Spain & 1.5 & Lu et al. [55] \\
\hline & \multirow[t]{2}{*}{ Shatsky Rise, North Pacific } & 3.5 & Tripati and Elderfield [7] \\
\hline & & 3.5 & Zachos et al. [1] \\
\hline & \multirow[t]{2}{*}{ Walvis Ridge, South Atlantic } & 2.5 & Shackleton and Hall [56] \\
\hline & & 3.5 & Tripati and Elderfield [7] \\
\hline & \multirow[t]{2}{*}{ Allison Guyot, Eq. Pacific } & 2.0 & Bralower et al. [57] \\
\hline & & 2.5 & Tripati and Elderfield [7] \\
\hline & Coastal sea, Uzbekistan & 2.5 & Bolle et al. (2002) \\
\hline \multirow[t]{15}{*}{ Benthic forams } & \multirow[t]{2}{*}{ Maud Rise, Weddell Sea } & 2.0 & Kennett and Stott [4] \\
\hline & & 1.5 & Thomas et al. [5] \\
\hline & Kerguelen Plateau, Indian Ocean & 2.0 & Lu and Keller [53] \\
\hline & Allison Guyot, Eq. Pacific & 1.5 & Bralower et al. [7] \\
\hline & Coastal sea, Kazahkstan & 1.0 & Bolle et al. (2002) \\
\hline & Blake Nose, North Atlantic & 2.0 & Katz et al. [58] \\
\hline & Alademilla section, Spain & 1.5 & Lu et al. [55] \\
\hline & Coastal Sea, New Jersey, USA & 4.0 & Cramer et al. [59] \\
\hline & Shatsky Rise, North Pacific & 1.5 & Tripati and Elderfield [7] \\
\hline & Walvis Ridge, South Atlantic & 2.5 & Tripati and Elderfield [7] \\
\hline & Indian Ocean & 0.5 & Nunes and Norris [60] \\
\hline & Bay of Biscay, North Atlantic & 1.5 & Nunes and Norris [60] \\
\hline & Goban Spur, North Atlantic & 2.5 & Nunes and Norris [60] \\
\hline & Tropical Pacific & $1-2$ & Nunes and Norris [60] \\
\hline & Demerara Rise, Eq.Atlantic & 2.5 & Nunes and Norris [60] \\
\hline Coccolithophorids & Maud Rise, Weddell Sea & 2.0 & Stoll $[61]$ \\
\hline \multirow[t]{5}{*}{ Bulk carbonate } & Walvis Ridge, South Atlantic & $2-2.5$ & Zachos et al. [8] \\
\hline & \multirow[t]{2}{*}{ Continental margin, New Zealand } & 1.0 & Crouch et al. [10] \\
\hline & & 1.5 & Hollis et al. [62] \\
\hline & Coastal sea, New Jersey, USA & 2.0 & Zachos et al. [6] \\
\hline & Goban Spur, North Atlantic & 2.0 & Cramer et al. [63] \\
\hline \multirow[t]{8}{*}{ Bulk organic } & Coastal sea, Uzbekistan & 6.0 & Bolle et al. [64] \\
\hline & Coastal lagoon, Belgium & 4.0 & Magioncalda et al. [65] \\
\hline & Coastal sea, Egypt & 3.0 & Schmitz et al. [66] \\
\hline & Coastal sea, Denmark & 7.5 & Schmitz et al. [66] \\
\hline & \multirow[t]{2}{*}{ Continental margin, New Zealand } & 2.0 & Kaiho et al. [40] \\
\hline & & 2.0 & Crouch et al. [10] \\
\hline & Arctic Ocean & 6.0 & Sluijs et al. [3] \\
\hline & North Sea & 5.5 & Sluijs [67] \\
\hline \multirow[t]{2}{*}{ Dinoflagellate cysts } & \multirow[t]{2}{*}{ Coastal sea, New Jersey, USA } & 4.0 & Sluijs [67] \\
\hline & & 4.5 & Sluijs [67] \\
\hline
\end{tabular}

CIE is differently reflected in angiosperms compared to gymnosperms thereby explaining the large CIE observed in terrestrial $n$-alkanes.

\section{Material and methods}

\subsection{Sampling strategy}

Sediments were obtained from Hole 4A drilled during IODP Expedition 302 on the Lomonosov Ridge [26].
Samples $(1-3 \mathrm{~g})$ were taken at ca. $20 \mathrm{~cm}$ intervals in sections 32X, 31X, 30X and 29X [3]. The position of the $\sim 55 \mathrm{~cm}$ sediments recovered of Core $31 \mathrm{X}$ relative to Cores $30 \mathrm{X}$ and $32 \mathrm{X}$ is uncertain. Due to the fact that this section was recovered from a core-catcher (CC), it was assigned meters below sea floor (mbsf) depths shipboard, as if it was directly underlying the bottom of Core $31 \mathrm{X}$, whilst a meters composite depth (med) was not given [26]. Because the origin of the $\sim 55 \mathrm{~cm}$ of sediments that comprise Core $31 \mathrm{X}$ relative to those of Cores 
Table 2

Summary of reported magnitudes (rounded off to $0.5 \%$ precision) of carbon isotope excursions in terrestrial sections during the PETM

\begin{tabular}{|c|c|c|c|}
\hline Source & Location & Excursion (\%o vs VPDB) & Reference \\
\hline \multirow[t]{6}{*}{ Bulk carbonate } & \multirow[t]{3}{*}{ Bighorn Basin, USA (paleosol) } & 4.5 & Koch et al. [17] \\
\hline & & 6.0 & Bowen et al. [15] \\
\hline & & $5.5-8$ & Bains et al. [68] \\
\hline & Bighorn Basin, USA (enamel apatite) & 6.0 & Koch et al. [17] \\
\hline & Tremp Basin, Spain (paleosol) & 6.0 & Schmitz and Pujalte [69] \\
\hline & Hengyang Basin, China (paleosol) & 5.0 & Bowen et al. [15] \\
\hline \multirow[t]{2}{*}{ Bulk organic } & \multirow[t]{2}{*}{ Bighorn Basin, USA } & 4.0 & Magioncalda et al. [65] \\
\hline & & 3.0 & Wing et al. [2] \\
\hline Bulk lignite & Cobham Lignite Bed, UK & 1.5 & Collinson et al. [70] \\
\hline \multirow[t]{3}{*}{$N$-alkanes } & Tawanui, New Zealand & 2.5 & Kaiho et al. [40] \\
\hline & Arctic continent & 4.5 & Pagani et al. [14] \\
\hline & Walvis Ridge & 4.5 & Hasegawa et al. [42] \\
\hline Conifer biomarkers & Arctic continent & 3.0 & This study \\
\hline Angiosperm biomarker & Arctic continent & 6.0 & This study \\
\hline
\end{tabular}

$30 \mathrm{X}$ and $32 \mathrm{X}$ is unclear, and for the sake of clarity, we applied the depths of Sluijs et al. [3], who plotted Core $31 \mathrm{X}$ data points $1 \mathrm{~m}$ lower than indicated in Backman et al. [26].

\subsection{Extraction and fractionation of biomarkers}

Samples were freeze-dried and were extracted using an accelerated solvent extractor (Dionex ASE 200) with a dichloromethane/methanol $(9: 1, \mathrm{v} / \mathrm{v})$ mixture to obtain the total extracts. The extracts, to which an ante-iso $\mathrm{C}_{22}$ $n$-alkane standard was added for quantitative analyses, were further separated into apolar and polar fractions on a column filled with alumina powder (activated for $2 \mathrm{~h}$ at $\left.150{ }^{\circ} \mathrm{C}\right)$ and elution with hexane/dichloromethane (9:1, $\mathrm{v} / \mathrm{v} ; 3 \times$ column volume) and methanol/dichloromethane $(1: 1, \mathrm{v} / \mathrm{v} ; 3 \times$ column volume), respectively. Saturated and aromatic compounds in the apolar hydrocarbon fractions were separated using a $\mathrm{AgNO}_{3}$-impregnated silica column (volume $3 \mathrm{ml}$ ) eluted with hexane $(3 \times$ column volume) and ethyl acetate $(3 \times$ column volume), respectively. The apolar, aliphatic and aromatic fractions were analysed by gas chromatography (GC), GC/mass spectrometry (MS) and GC/isotope ratio monitoring MS (GC/irmMS).

\subsection{Instrumental analysis of biomarkers}

To quantify biomarker concentrations, GC analyses were performed on the different fractions dissolved in hexane, using a Hewlett-Packard 5890 (6890) instrument equipped with a flame ionization detector (FID) and an on-column injector. A fused silica capillary column $(25 \mathrm{~m} \times 0.32 \mathrm{~mm})$ coated with CP-Sil 5 (film thickness $0.12 \mu \mathrm{m}$ ) was used with helium as carrier gas. The oven was programmed at a starting (injection) temperature of $70^{\circ} \mathrm{C}$, which rose to $130{ }^{\circ} \mathrm{C}$ at $20^{\circ} \mathrm{C} / \mathrm{min}$ and then to $320{ }^{\circ} \mathrm{C}$ at $4{ }^{\circ} \mathrm{C} / \mathrm{min}$, at which it was maintained for $20 \mathrm{~min}$.

The different fractions were analysed by GC/MS using a Finnigan Trace GC ultra coupled to a Finnigan Trace DSQ mass spectrometer. GC conditions and column were as described above. The column was directly inserted into the electron impact ion source of the DSQ quadrupole mass spectrometer, scanning a mass range of $m / z 50-800$ at 3 scans per second and an ionization energy of $70 \mathrm{eV}$.

Compound-specific $\delta^{13} \mathrm{C}$ analyses were performed for aromatic hydrocarbon fraction. Samples were analysed on a Finnigan Delta $\mathrm{C}$ isotope ratio monitoring gas chromatography mass spectrometer. The GC column conditions and temperature program were the same as described above for GC analyses. The $\delta^{13} \mathrm{C}$ values for individual compounds are reported in the standard delta notation against the Vienna Pee Dee Belemnite (VPDB) standard and are the means of duplicate runs with a reproducibility of on average $0.5 \%$.

\section{Results}

\subsection{Biomarker compositions}

GC/MS analysis of the apolar hydrocarbon fractions revealed substantial differences in compositions between sediments deposited before and after the CIE (Fig. 1a and c) and sediments deposited during the CIE (Fig. 1b) (see [14]). In sediments deposited before (390.7-388.6 mbsf) and after (378.51-377.51 mbsf) the CIE, the apolar hydrocarbon fraction is dominated by $\mathrm{C}_{23}-\mathrm{C}_{35} n$-alkanes with a large odd-over-even carbon number predominance and by abundance of aromatic diterpenoids, dehydroabietane and simonellite [27], and 
a tetra-aromatic triterpane [28] (Fig. 1a). High carbon numbered $n$-alkanes with an odd-over-even predominance are typical for terrestrial plant waxes [29]. Dehydroabietane and simonellite are diagenetic products of abietic acid, an abundant diterpenoid in conifer plants [27] (Fig. 2), whilst the tetra-aromatic triterpane is an early diagenetic product of $\beta$-amyrin [28] (Fig. 2), an abundant triterpenoid in angiosperms. In addition to these terrestrial biomarkers, there was a relatively high amount of $\mathrm{C}_{31} 17 \beta, 21 \beta(\mathrm{H})$-hopane and lower amounts of the $\mathrm{C}_{32}-\mathrm{C}_{35} 17 \beta, 21 \beta(\mathrm{H})$-hopanes. These compounds can be derived from both terrestrial and marine bacterial sources. The high abundance of the $17 \beta, 21 \beta(\mathrm{H})$-stereoisomers attest to the relative immaturity of the organic matter [30].
The apolar hydrocarbon composition in sediments deposited during the initial part of the CIE (387.6$383.3 \mathrm{mbsf}$ ) is a far more complex mixture with less well-resolved peaks (e.g. Fig. 1b). The most abundant compounds are phytane and hop-(17,21)-ene with somewhat lower amounts of the monoaromatic derivative of isorenieratene $[31,32]$. The terrestrial biomarkers present in the pre-CIE sediments, i.e. odd carbon number $\mathrm{C}_{25}-\mathrm{C}_{33} n$-alkanes, dehydroabietane, simonellite and the tetra-aromatic derivative of beta-amyrin, were also present in the CIE sediments but in much lower relative abundance.

Quantification of the concentration of the different biomarkers showed that dehydroabietane, simonellite and the tetra-aromatic triterpane were relatively abundant
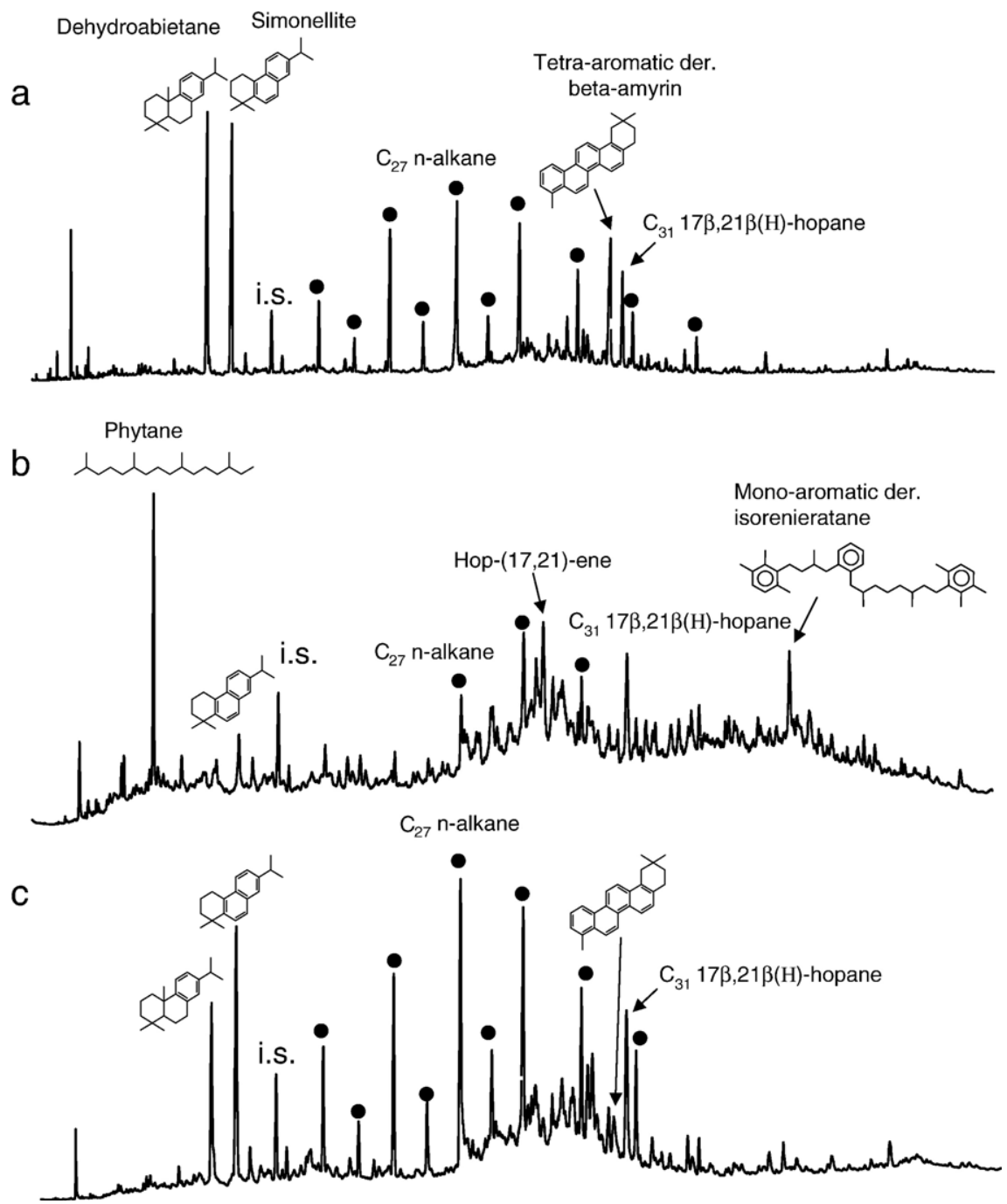

Fig. 1. Gas chromatogram of apolar fractions of total extracts of sediments from (a) 390.31 mbsf depth (pre-PETM), (b) 383.94 mbsf depth (PETM) and (c) 377.91 mbsf depth (post-PETM). Filled circles indicate homologous series of $n$-alkanes. 


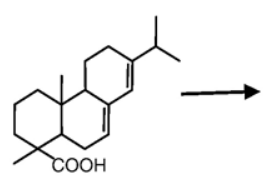

Abietic acid<smiles>CC(C)c1ccc2c(c1)CC(C)C1CCCC(C)(C(=O)O)C21C</smiles>

Dehydroabietane<smiles>CC(C)c1ccc2c(c1)CCC1C(C)(C)CCCC21C</smiles>

Simonellite

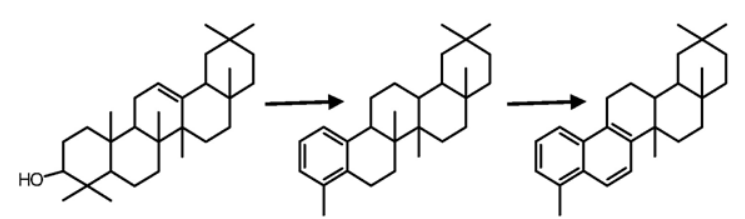

$\beta$-Amyrin

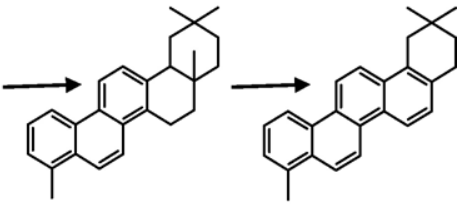

Tetra-aromatic triterpane

Fig. 2. Diagenetic scheme showing the formation of dehydroabietane and simonellite from abietic acid and the formation of the tetra-aromatic triterpane from $\beta$-amyrin (after Simoneit [52]).

prior to the CIE but then decreased substantially during the initial phase of the CIE (Fig $3 \mathrm{~b}$ and c). In contrast, the concentration of the $\mathrm{C}_{29} n$-alkane does not show substantial differences in concentration before, during and after the CIE (Fig. 3c). The relative ratio of the angiosperm biomarker versus that of the conifer biomarkers remained fairly constant except for an increase in angiosperm biomarkers during the recovery of the CIE (Fig. 3e). Biomarkers like phytane, hop-(17,21)-ene and derivatives of isorenieratene were in low abundance or even absent before the CIE but became abundant at the initial phase of the CIE and then slowly decreased again to pre-CIE concentrations (Fig. $3 \mathrm{f}$ and $\mathrm{g}$ ).

\subsection{Compound-specific stable carbon isotope records}

Stable carbon isotopic analyses were performed, where possible, on dehydroabietane and simonellite as biomarkers for conifers and the tetra-aromatic derivative of $\beta$-amyrin as a marker for angiosperms. Isotopic analysis was mostly performed on purified aromatic hydrocarbon fractions to enhance the concentration of

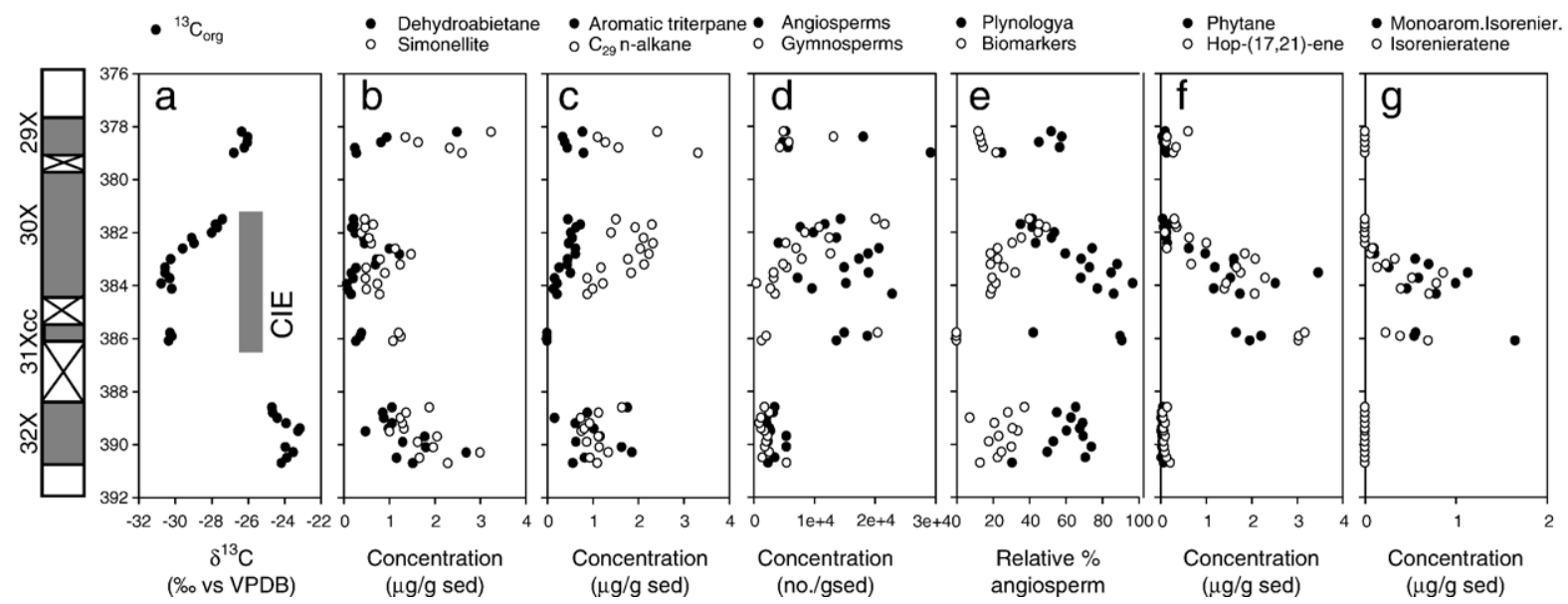

Fig. 3. Depth profile of (a) $\delta^{13} \mathrm{C}$ of total organic carbon (from Sluijs et al. [3], (b) concentrations of dehydroabietane and simonellite, (c) concentrations of the tetra-aromatic derivative of $\beta$-amyrin and $\mathrm{C}_{29} n$-alkane, (d) amount of angiosperm and gymnosperm pollen (from Sluijs et al. [3]), (e) relative percentage of angiosperms compared to total of angiosperms and gymnosperms based on palynology (pollen counts) and biomarkers (concentrations of dehydroabietane + simonellite and tetra-aromatic triterpane), (f) concentrations of phytane and hop-(17,21)-ene and (g) concentrations of isorenieratane and its monoaromatic derivative. 

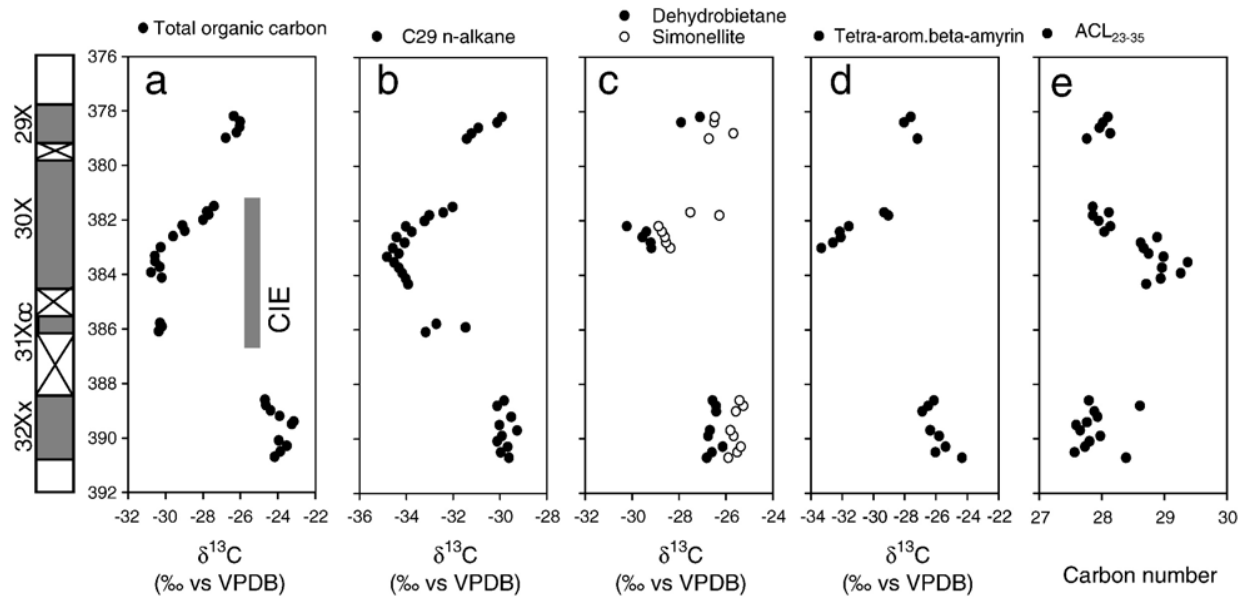

Fig. 4. Depth profile of the $\delta^{13} \mathrm{C}$ values of (a) total organic carbon, (b) $\mathrm{C}_{29} n$-alkane (from Pagani et al. [14]\} (c) dehydroabietane and simonellite and (d) the tetra-aromatic derivative of $\beta$-amyrin and (e) the Average Chain Length (ACL) of $\mathrm{C}_{23}-\mathrm{C}_{35} n$-alkanes.
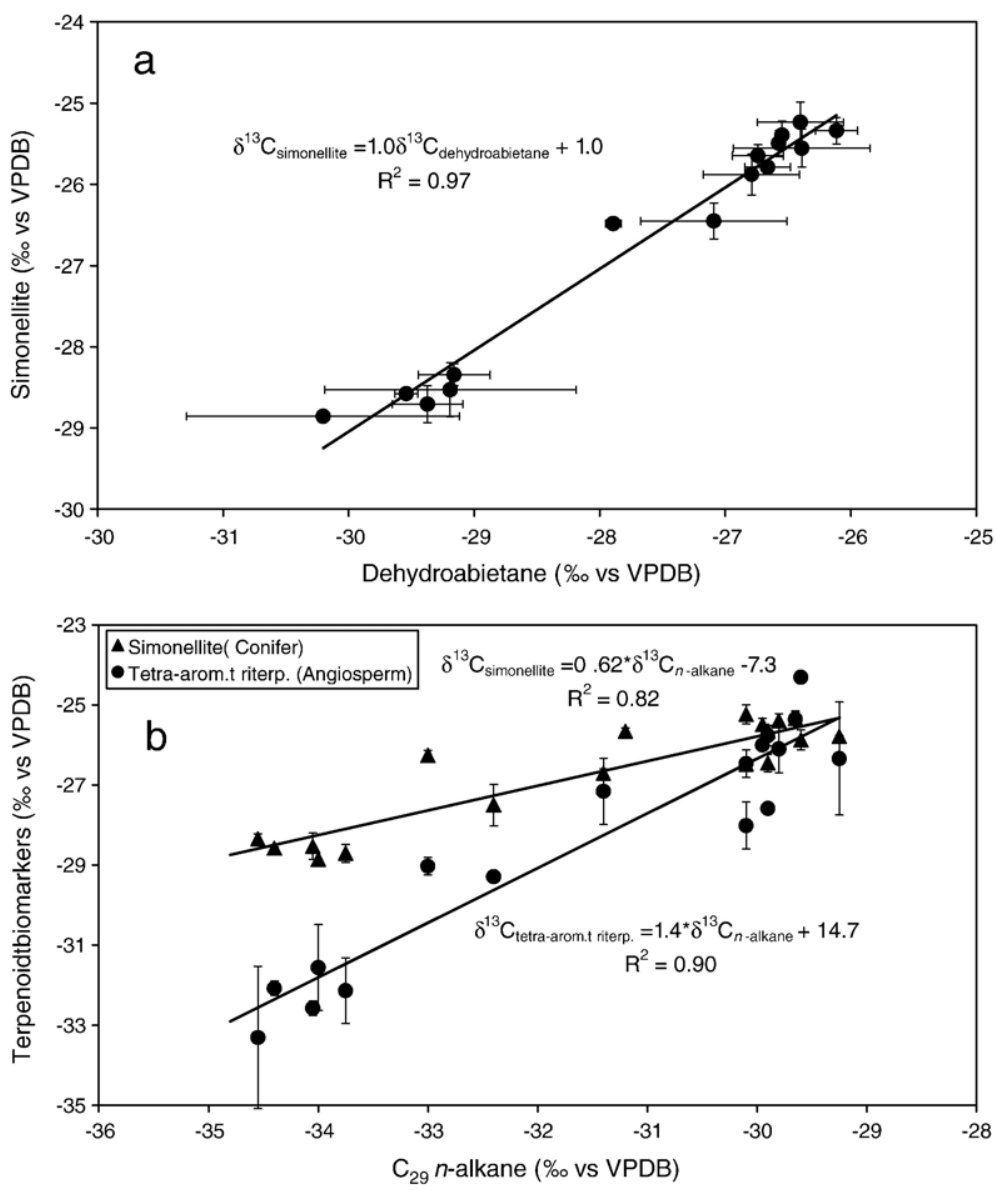

Fig. 5. Cross plots of $\delta^{13} \mathrm{C}$ values of (a) dehydroabietane against simonellite and (b) simonellite and tetra-aromatic derivative of $\beta$-amyrin against the $\mathrm{C}_{29} n$-alkane Error bars are standard deviations of replicate analysis. 
these aromatic biomarkers. Despite this, the isotopic composition of these compounds could not be obtained for all samples due to low abundances, high backgrounds or coelutions with other compounds. This was especially the case during the initial stages of the CIE, as defined by the $\delta^{13} \mathrm{C}$ records of total organic carbon [3] and the terrestrial $\mathrm{C}_{29} n$-alkane [14] (Fig. 3), when high amounts of other compounds and an unresolved complex mixture severely diminished the relative abundance of the terrestrial biomarkers.

The results show that dehydroabietane and simonellite have $\delta^{13} \mathrm{C}$ values of ca. -25 to $-26 \%$ prior the $\mathrm{CIE}$ and then both became more negative by up to $3 \%$ during the $\mathrm{CIE}$ and returned to more ${ }^{13} \mathrm{C}$-enriched values after the CIE at ca. $-26 \%$ although still slightly more depleted compared to pre-CIE values (Fig. 4c). The $\delta^{13} \mathrm{C}$ values of dehydroabietane and simonellite are significantly correlated to each other $\left(r^{2}=0.97\right.$; Fig. 5a) in agreement with their common origin, i.e., abietic acid synthesized by conifers. The tetra-aromatic triterpane had similar $\delta^{13} \mathrm{C}$ values as the conifer biomarkers prior the CIE, i.e. ca. $-26 \%$, but was strongly depleted by up to $6 \%$ during the CIE (Fig. $4 \mathrm{c}$ ). The $\delta^{13} \mathrm{C}$ value of the angiosperm biomarker then rapidly decreased during the recovery phase of the CIE but remained depleted in ${ }^{13} \mathrm{C}$ post-CIE at ca. $-28 \%$.

\section{Discussion}

\subsection{Terrestrial vegetation changes}

Our results show that the concentrations of biomarkers derived from gymnosperms and angiosperms decreased during the most of the CIE and increased after the CIE (Fig. 3b and c). These results are somewhat different from that of pollen analysis of the same core (Fig. 3d): the absolute abundance of gymnosperm pollen is low before and during most of the CIE and increases only at the end and after the CIE whilst that of angiosperm pollen strongly increased during CIE and remained relatively high. The relative percentage of angiosperm pollen of summed angiosperm + gymnosperm pollen was slightly higher during the CIE than before and decreased after the event (Fig. 3e, [3]). In contrast, the relative percentage of the angiosperm biomarker of the summed angiosperm + conifer biomarkers was relatively similar during the CIE and increased at the end of the CIE (Fig. 3d). The differences observed between the biomarkers and pollen may be due to, for example, an incomplete inventory of biomarkers derived from angiosperms and gymnosperms. Alternatively, biomarkers and pollen have different taphonomies and can be transported from land to the marine environments in different ways, i.e., via aeolian or fluvial transport with likely different relative contributions. Indeed, the concentration profile of the $C_{29}$ $n$-alkane is different from that of the terrestrial aromatic biomarkers which may be due to this effect. Higher plant wax $n$-alkanes are known to be transported both by wind and riverine input (e.g. [33]). Finally, other factors which can introduce biases into the biomarker and pollen records include differential preservation and sedimentation rates, winnowing and changes in plant communities.

There is also a shift in the relative distribution of $n$-alkanes which can be expressed as the Average Chain Length (ACL) of $\mathrm{C}_{23}$ to $\mathrm{C}_{35} n$-alkanes (Fig. 4e). Prior to the CIE the $\mathrm{ACL}_{23-35}$ is approximately 27.8 but then changes at the onset of the CIE to 28.9, i.e. a shift towards longer chain $n$-alkanes. During the recovery phase of the CIE distribution of the $n$-alkanes shifts back to shorter chain lengths with the $\mathrm{ACL}_{23-35}$ gradually moving back to approximately 28.0 at which it remains after the CIE. The ACL of plant waxes varies widely between different species (e.g. [25]) and thus this change in $\mathrm{ACL}_{23-35}$ could reflect changes in vegetation, as recorded in the pollen assemblages [3]. Indeed, the depth profile in $\mathrm{ACL}_{23-35}$ resembles that of the $\%$ angiosperm pollen profile (Fig. 3e). However, a number of studies have also shown that with increasing temperature and/or aridity the ACL increases (e.g. [33-36]). Sachse et al. [36] observed a significant increase in ACL with increasing hydrogen isotopic fractionation. As hydrogen isotopic fractionation of plants is strongly depending on net evaporation they suggested that plants increase the average chain lengths of their plant wax $n$-alkanes to minimize the enhanced evaporation from their leaves [36]. Thus, the strong increase $\mathrm{ACL}_{23-35}$ observed here during the initial phase of the CIE may have been a response to enhanced evaporation due to increased temperatures [37].

\subsection{Magnitude of CIE in ${ }^{13} C$-contents of terrestrial organic carbon}

The $\delta^{13} \mathrm{C}$ values of the terpenoid biomarkers likely represent the original $\delta^{13} \mathrm{C}$ values of their parent compound, i.e. abietic acid and $\beta$-amyrin (Fig. 2), as aromatization has been shown not to significantly affect the stable carbon isotopic composition of compounds $[38,31]$. The enriched $\delta^{13} \mathrm{C}$ values of the terpenoid biomarkers compared to the $n$-alkanes is in agreement with fractionation induced during biosynthesis of these compounds, i.e., in general straight chain carbon skeletons are depleted in ${ }^{13} \mathrm{C}$ compared to isoprenoid skeletons in plants [39]. The stable isotope analyses of 
angiosperm and conifer biomarkers reveal that these vegetation types have different negative CIEs: Conifers expressed an excursion of up to ca. 3\% whilst angiosperms had a CIE of up to $6 \%$. Although we do not have stable isotope data at the start of the CIE in our section (384.34 to $383.22 \mathrm{mbsf}$ ) it is likely that these CIEs are not much larger than this since both TOC and $\delta^{13} \mathrm{C}$ of the $\mathrm{C}_{29} n$-alkanes are relatively constant from to 384.34 to $382.62 \mathrm{msbf}$ (Fig. 4) $[3,14]$.

Our results can now readily explain the observed CIE in the terrestrial $n$-alkanes of $4.5 \%$ as reported previously [14]. Both conifers and angiosperms contributed to the $n$-alkane pool and thus to their isotopic signature. Indeed, the $\delta^{13} \mathrm{C}$ values of both conifer and angiosperm biomarkers significantly correlate to that of the $\mathrm{C}_{29} n$-alkane (Fig. 5b). However, the slope of the correlation lines is different: a change of $1 \%$ in the $\mathrm{C}_{29}$ $n$-alkane corresponds to a change of ca. $0.6 \%$ in the conifer biomarkers and ca $1.4 \%$ in the angiosperm biomarker. Indeed, the average CIE of the $\mathrm{C}_{29} n$-alkane is $4.5 \%$ which is in between the $3 \%$ CIE in conifers and the $6 \%$ CIE in angiosperms, suggesting that the terrestrial $n$-alkanes and their isotopic composition represent a mixture of $n$-alkanes sourced by angiosperms and conifers.

Our results can potentially explain other excursions reported for terrestrial derived $n$-alkanes. A relatively small CIE (ca. 2.5\%) has been observed in the $\mathrm{C}_{29}$ $n$-alkane in the Tawanui section, New Zealand [40]. Palynological investigations have revealed that the terrestrial vegetation input in this section is dominated by conifers with a relatively low $(<5 \%)$ abundance of angiosperms and no substantial changes throughout the CIE [41]. Thus, the $\mathrm{C}_{29} n$-alkane in this section is primarily sourced by conifers in this area, strongly suggesting that conifers in the mid to high latitude Southern Hemisphere also expressed a CIE of ca. 3\%. However, it should be noted that in this section the initial phase of the CIE is likely absent [40] and thus the full extend of the CIE in the terrestrial $n$-alkane may have not been recorded. Hasegawa et al. [42] reported a $4\left(\mathrm{C}_{31} n\right.$-alkane $)$ to $5 \%$ o $\left(\mathrm{C}_{29} n\right.$-alkane) excursion in odd carbon numbered $n$-alkanes in sediments deposited at Walvis Ridge. These $n$-alkanes are likely derived through aeolian transport from the southern part of Africa [43] which probably have been dominated by angiosperms. This suggests that angiosperms in this part of the world also had a larger CIE by up to $2 \%$ compared to that inferred for atmospheric $\mathrm{CO}_{2}$. Potentially, this excursion may be even larger as the sample resolution in the study of Hasegawa et al. [42] was relatively low and the authors noted some problems with contamination of the $n$-alkanes from drilling fluids. These studies tentatively suggest that our observation of varying CIEs for conifers and angiosperms may be a global phenomenon although more sites need to be investigated to substantiate this hypothesis. If confirmed, it may partly explain the large and variable CIEs recorded from terrestrial sections (Table 2).

The different CIE of conifers versus that of angiosperms is intriguing and has, to the best of our knowledge, not been previously observed. Two end-member explanations can be proposed for this observation: $\boldsymbol{i}$ ) the CIE of the conifer biomarkers (3\%o) represents the general CIE of atmospheric $\mathrm{CO}_{2}$, similar to that inferred from marine carbonates (Table 1), and angiosperms increasingly fractionate in ${ }^{13} \mathrm{C}$ during the CIE or ii) the CIE of the angiosperms (6\%) represents the general CIE of atmospheric $\mathrm{CO}_{2}$, a much larger CIE than previously assumed, and the conifer biomarkers have reduced isotopic fractionation during the CIE. However, such a large $\mathrm{CIE}$ in atmospheric $\mathrm{CO}_{2}$ seems unlikely as nearly all marine and terrestrial isotope records have a much smaller CIE (Tables 1 and 2). Thus, it seems more likely that angiosperms increased their isotopic fractionation during the CIE in contrast to conifers which remain relatively constant in isotopic fractionation.

The fractionation in ${ }^{13} \mathrm{C}$ of terrestrial $\mathrm{C} 3$ plants is strongly correlated to the relative concentration of internal $\left(c_{\mathrm{i}}\right) \mathrm{CO}_{2}$ to ambient $\left(c_{\mathrm{a}}\right) \mathrm{CO}_{2}[44]$ :

$\Delta=\mathrm{a}+(b-\mathrm{a})^{*} c_{\mathrm{i}} / c_{\mathrm{a}}$

where $\Delta$ is the isotopic fractionation of plants, $\mathrm{a}=$ fractionation due to diffusion of $\mathrm{CO}_{2}$ through the stomata (ca 4.4\%o) and $b$ is fractionation by Rubisco (ca. 27\%o). Our data thus suggest that the $c_{\mathrm{i}} / c_{\mathrm{a}}$ of angiosperms has increased whilst that of conifers has remained relatively constant. The relative ratio of $c_{\mathrm{i}} / c_{\mathrm{a}}$ is negatively related to water use efficiency (WUE), i.e. the amount of carbon assimilated per amount of water used [44]:

$\mathrm{WUE}=\frac{A}{g}=\frac{c_{\mathrm{a}}\left(1-c_{\mathrm{i}} / c_{\mathrm{a}}\right)}{1.6}$

where $A$ is the $\mathrm{CO}_{2}$ assimilation rate and $g$ is the stomatal conductance. Our results thus suggest that the WUE of angiosperms has likely decreased relative to that of conifers. For conifers our isotope evidence suggests that $c_{\mathrm{i}} / c_{\mathrm{a}}$ remained constant but as $c_{\mathrm{a}}$ likely increased during the CIE (e.g. [45]) Eq. (2) implies that the WUE of conifers increased. Unfortunately, little information is available on the effect on long term ( $>100 \mathrm{yr}$ ) exposure to higher $\mathrm{CO}_{2}$ levels on changes in WUE in higher plants and concern at best decadal time 
scales. The data generally show that plants increase their WUE at increasing $\mathrm{CO}_{2}$ levels (e.g. [46-48]), as likely has been the case for conifers during the CIE, but substantial differences in WUE changes with different plant species have, to the best of our knowledge, not been reported. However, most of the data which examined the change in WUE under changing temperature and $\mathrm{CO}_{2}$ conditions were obtained from short term experiments $(<10 \mathrm{yr})$ and under conditions not relevant for the $\mathrm{P}-\mathrm{E}$ where, e.g., $\mathrm{CO}_{2}$ levels were likely above $1100 \mathrm{ppmv}$ [49-51]. The reason for the different physiological response of angiosperms and conifers thus remains enigmatic. One speculative possibility is that it was evolution-driven. Angiosperm plants that evolved during the early Paleogene likely had optimal WUE for greenhouse conditions, possibly aided by the increased chain length of their plant waxes, even at the warm low latitudes. Hence, their WUE may already have been fully adapted to the warm conditions which ensued upon the high latitude continents during the PETM. Possibly, even during the extreme warm conditions of the PETM they were able to keep their WUE rather constant, which, as $c_{\mathrm{a}}$ rose, led to a decrease in $c_{\mathrm{i}} / c_{\mathrm{a}}$ and an increase in carbon isotopic fractionation. In contrast, conifers, which were mostly restricted to the relatively cool higher latitudes during the late Paleocene, may have adapted themselves to the warming conditions with improved WUE leading to a more or less constant $c_{\mathrm{i}} / c_{\mathrm{a}}$ and thus constant isotopic fractionation.

\section{Conclusions}

Molecular isotopic analysis of terrestrial biomarkers deposited during the Paleocene-Eocene in the Arctic Ocean revealed that conifers and angiosperms reacted differently in isotopic fractionation during the CIE. This led to different isotopic excursions of ca. 3\% for conifers and $6 \%$ for angiosperms. The $\mathrm{C}_{29} n$-alkane isotope excursion of ca. $4.5 \%$ previously reported from the same material likely represents a mixed signal of both the angiosperm and conifer isotopic excursions. The different CIE of conifers and angiosperms can thus lead to a large and variable CIE in terrestrial isotope records depending on the relatively dominance of the two vegetation types and care has to be taken when interpreting the magnitude of CIEs of terrestrial $\mathrm{P}-\mathrm{E}$ records. Our data suggest that under the already extreme conditions of late Paleocene climate and the rapid climate change during the $\mathrm{P}-\mathrm{E}$ the different vegetation types had different physiological responses resulting in different carbon isotope fractionation patterns.

\section{Acknowledgements}

We thank M. van der Meer (NIOZ) for assistance with isotope analysis. S. Wing, G. Bowen and M. Pagani are thanked for useful discussions. This research used samples and data provided by the Integrated Ocean Drilling Program (IODP). IODP is sponsored by the U.S. National Science Foundation (NSF) and participating countries under management of Joint Oceanographic Institutions (JOI) Incorporated. We thank the Netherlands Organization for Scientific Research (NWO) for their continued support of ODP and IODP.

\section{References}

[1] J.C. Zachos, M.W. Wara, S. Bohaty, M.L. Delaney, M.R. Petrizzo, A. Brill, T.J. Bralower, I. Premoli-Silva, A transient rise in tropical sea surface temperature during the Paleocene-Eocene thermal maximum, Science 302 (2003) 1151-1154.

[2] S.L. Wing, G.J. Harrington, F.A. Smith, J.I. Bloch, D.M. Boyer, K.H. Freeman, Transient floral change and rapid global warming at the Paleocene-Eocene boundary, Science 310 (2005) 993-996.

[3] A. Sluijs, S. Schouten, M. Pagani, M. Woltering, H. Brinkhuis, J.S Sinninghe Damsté, G.R. Dickens, M. Huber, G.-J. Reichart, R Stein, J. Matthiessen, L.J. Lourens, N. Pedentchouk, J. Backman, K. Moran, The Expedition 302 Scientists, Subtropical Arctic Ocean temperatures during the Palaeocene-Eocene thermal maximum, Nature 441 (2006) 610-613.

[4] J.P. Kennett, L.D. Stott, Abrupt deep-sea warming, palaeoceanographic changes and benthic extinctions at the end of the Palaeocene, Nature 353 (1991) 225-229.

[5] D.J. Thomas, J.C Zachos, T.J. Bralower, E. Thomas, S. Bohaty, Warming the fuel for the fire: evidence for the thermal dissociation of methane hydrate during the Paleocene-Eocene thermal maximum, Geology 30 (2002) 1067-1070.

[6] J.C. Zachos, S. Schouten, S. Bohaty, T. Quattlebaum, A. Sluijs, H. Brinkhuis, S. Gibbs, T.J. Bralower, Extreme warming of midlatitude coastal ocean during the Paleocene-Eocene Thermal Maximum: inferences from $\mathrm{TEX}_{86}$ and isotope data, Geology 34 (2006) 737-740.

[7] A. Tripati, H. Elderfield, Deep-sea temperature and circulation changes at the Paleocene-Eocene thermal maximum, Nature 308 (2005) 1894-1898.

[8] J.C. Zachos, U. Rohl, S.A. Schellenberg, A. Sluijs, D.A. Hodell, D.C. Kelly, E. Thomas, M. Nicolo, I. Raffi, L.J. Lourens, H. McCarren, D. Kroon, Rapid acidification of the ocean during the Paleocene-Eocene thermal maximum, Science 308 (2005) $1611-1615$

[9] J.P. Bujak, H. Brinkhuis, Global warming and dinocyst changes across the Paleocene-Eocene epoch boundary, in: M.P. Aubry, W.A. Berggren (Eds.), Late Paleocene-Early Eocene, Columbia University Press, New York, 1998, pp. 277-295.

[10] E.M. Crouch, G.R. Dickens, H. Brinkhuis, M.-P. Aubry, C.J. Hollis, K.M. Rogers, H. Visscher, The Apectodinium acme and terrestrial discharge during the Paleocene-Eocene thermal maximum: new palynological, geochemical and calcareous nannoplankton observations at Tawanui, New Zealand, Palaeogeogr. Palaeoclimatol. Palaeoecol. 194 (2003) 387-403.

[11] A. Sluijs, G.J. Bowen, H. Brinkhuis, L.J., Lourens, E. Thomas, The Paleocene-Eocene Thermal Maximum super greenhouse: 
biotic and geochemical signatures, age models and mechanisms of global change. In: M. Williams, A. Haywood, J. Gregory, D.N. Schmidt (Eds), Deep time perspectives on Climate Change. Geological Society of London, TMS Special Publication, London, in press.

[12] E. Thomas, N. Shackleton, The Palaeocene-Eocene benthic foraminiferal extinction and stable isotope anomalies, in: R.W. O'B. Knox, R.M. Corfield, R.E. Dunay (Eds.), Correlation of the Early Paleogene in Northwest Europe, Geol. Soc. Spec. Publ. London, vol. 101, 1996, pp. 401-441.

[13] G.J. Bowen, D.J. Beerling, P.L. Koch, J.C. Zachos, T.A. Quattlebaum, A humid climate state during the Palaeocene/ Eocene thermal maximum, Nature 432 (2004) 495-499.

[14] M. Pagani, N. Pedentchouk, M. Huber, A. Sluijs, S. Schouten, H. Brinkhuis, J.S. Sinninghe Damsté, G.R. Dickens, IODP Expedition 302 Expedition Scientists, Arctic's hydrology during global warming at the Palaeocene-Eocene thermal maximum, Nature 442 (2006) 671-675.

[15] G.J. Bowen, W.C. Clyde, P.L. Koch, S. Ting, J. Alroy, T. Tsubamoto, Y. Wang, Mammalian dispersal at the Paleocene/Eocene boundary, Science 295 (2002) 2062-2065.

[16] P.D. Gingerich, Environment and evolution through the Paleocene-Eocene thermal maximum, Trends Ecol. Evol. 21 (2006) $246-253$.

[17] P.L. Koch, J.C. Zachos, P.D. Gingerich, Correlation between isotope records in marine and continental carbon reservoirs near the Palaeocene/Eocene boundary, Nature 358 (1992) 319-322.

[18] H. Svensen, S. Planke, A. Malthe-Sørenssen, B. Jamtveit, R. Myklebust, T.R. Eidem, S.S. Rey, Release of methane from a volcanic basin as a mechanism for initial Eocene global warming, Nature 429 (2004) 542-545.

[19] G.R. Dickens, J.R. O'Neil, D.K. Rea, R.M. Owen, Dissociation of oceanic methane hydrate as a cause of the carbon isotope excursion at the end of the Paleocene, Paleoceanography 10 (1995) 965-971.

[20] A.C. Kurtz, L.R. Kump, M.A. Arthur, J.C. Zachos, A. Paytan, Early Cenozoic decoupling of the global carbon and sulfur cycles, Paleoceanography 18 (2003) 1090, doi:10.1029/2003PA000908.

[21] J.A. Higgins, D.P. Schrag, Beyond methane: towards a theory for the Paleocene-Eocene thermal maximum, Earth Planet. Sci. Lett. 245 (2006) 523-527.

[22] R.E. Zeebe, J.C. Zachos, Reversed deep-sea carbonate ion basingradient during Paleocene-Eocene Thermal Maximum, Paleoceanography (in press), doi:10.1029/2006PA001395.

[23] S.W. Leavitt, T. Newberry, Systematics of stable-carbon isotopic differences between gymnosperm and angiosperm trees, Plant Physiol. (Adv. Life Sci.) 11 (1992) 257-262.

[24] A.P. Murray, D. Edwards, J.M. Hope, C.J. Boreham, W.E. Booth, R.A. Alexander, R.E. Summons, Carbon isotope biogeochemistry of plant resins and derived hydrocarbons, Org. Geochem. 29 (1988) 1199-1214.

[25] Y. Chikaraishi, H. Naraoka, Compound specific $\delta \mathrm{D}-\delta^{13} \mathrm{C}$ analysis of $n$-alkanes extracted from terrestrial and aquatic plants, Phytochemical 63 (2003) 361-371.

[26] J. Backman, K. Moran, D.B. McInroy, L.A. Mayer, ExpeditionScientists, Proceedings of the Integrated Ocean Drilling Program, vol. 302, Integrated Ocean Drilling Program Management International, Inc., College Station TX, 2006.

[27] B.R.T. Simoneit, 1975. Sources of organic matter in oceanic sediments, PhD Thesis, University of Bristol, England.

[28] C. Spyckerelle, A.C. Greiner, P. Albrecht, G. Ourisson, Hydrocarbons aromatiques d'origine geologique III. Un tetra- hydrochrysene, derive de triterpenes, dans des sediments recents et anciens: 3,3,7-trimethyl-1,2,3,4,tétrahydrochrysène, J. Chem. Res., Miniprint (1977) 3746-3754.

[29] G. Eglinton, R.J. Hamilton, Leaf epicuticular waxes, Science 156 (1967) 1322-1335.

[30] A.C.T. Van Duin, J.S. Sinninghe Damsté, M.P. Koopmans, B. v. d. Graaf, J.W. de Leeuw, A kinetic calculation method of homohopanoid maturation: application in the reconstruction of burial histories of sedimentary basins, Geochim. Cosmochim. Acta 61 (1997) 2409-2429.

[31] J.S. Sinninghe Damsté, J. Koster, M. Baas, M.P. Koopmans, H.M.E. van Kaam-Peters, J.A.J. Geenevasen, C. Kruk, Cyclisation and aromatisation of carotenoids during sediment diagenesis, J. Chem. Soc., Chem. Commun. (1995) 187-188.

[32] M.P. Koopmans, W.I.C. Rijpstra, M.M. Klapwijk, J.W. de Leeuw, M.D. Lewan, J.S. Sinninghe Damsté, A thermal and chemical degradation approach to decipher pristane and phytane precursors in sedimentary organic matter, Org. Geochem. 30 (1999) 1089-1104.

[33] J.G. Poynter, P. Farrimond, N. Robinson, G. Eglinton, Aeolianderived higher plant lipids in the marine sedimentary record: links with palaeoclimate, in: M. Leinen, M. Sarnthein (Eds.), Paleoclimatology and Paleometeorology: Modern and Past Patterns of Global Atmospheric Transport, Kluwer, Dordrecht, 1989, pp. 435-462.

[34] E. Schefuß, V. Ratmeyer, J.-B.W. Stuut, J.H.F. Jansen, J.S. Sinninghe Damsté, isotope analysis of n-alkanes in dust from the lower atmosphere over the eastern Atlantic, Geochim. Cosmochim. Acta 67 (2003) 757-1767.

[35] K.A. Hughen, T.I. Eglinton, L. Xu, M. Makou, Abrupt tropical vegetation response to rapid climate changes, Science 304 (2004) 1955-1959.

[36] D. Sachse, J. Radke, D. Gleixner, $\delta$ D values of individual n-alkanes from terrestrial plants along a climatic gradient - implications for the sedimentary biomarker record, Org. Geochem. 37 (2006) 469-483.

[37] J.W.H. Weijers, S. Schouten, H. Brinkhuis, J.S. Sinninghe Damsté, 2007. Warm Arctic continents during the PalaeoceneEocene thermal maximum. Earth. Plan. Sci. Lett. (submitted for publication).

[38] K.H. Freeman, C.J. Boreham, R.E Summons, J.M. Hayes, The effect of aromatization on the isotopic compositions of hydrocarbons during early diagenesis, Org. Geochem. 21 (1994) $1037-1050$.

[39] J.M. Hayes, Factors controlling ${ }^{13} \mathrm{C}$ contents of sedimentary organic compounds: principles and evidence, Mar. Geol. 113 (1993) 111-125.

[40] K. Kaiho, T. Arinobu, R. Ishiwatari, H.E.G. Morgans, H. Okada, N. Takeda, K. Tazaki, G.P. Zhou, Y. Kajiwara, R. Matsumoto, A. Hirai, N. Niitsuma, H. Wada, Latest Paleocene benthic foraminiferal extinction and environmental changes at Tawanui, New Zealand, Paleoceanography 11 (1996) 447-465.

[41] E.M. Crouch, H. Visscher, Terrestrial vegetation record across the initial Eocene thermal maximum at the Tawanui marine section, New Zealand, in: S.L. Wing, P.D. Gingrich, B. Schmitz, E. Thomas (Eds.), Causes and Consequences of Globally Warm Climates in the Early Paleogene, Geol. Soc. Am. Spec. Pap., vol. 369, 2003, pp. 351-363.

[42] T. Hasegawa, S. Yamamoto, L.M. Pratt, Data report: stable carbon isotope fluctuation of long-chain n-alkanes from Leg 208 Hole 1263A across the Paleocene/Eocene boundary, in: D. Kroon, J.C. Zachos, C. Richter (Eds.), Proc. ODP, Sci. Results, 
vol. 208, Ocean Drilling Program, College Station, TX, 2006, doi:10.2973/odp.proc.sr.208.202.2006.

[43] F. Rommerskirchen, G. Eglinton, L. Dupont, U. Guntner, C. Wenzel, J. Rullkotter, A north to south transect of Holocene southeast Atlantic continental margin sediments: relationship between aerosol transport and compound-specific delta C-13 land plant biomarker and pollen records, Geochem. Geophys. Geosyst. 4 (2003) 1101.

[44] G.D. Farquhar, J.R. Ehleringer, K.T. Hubick, Carbon isotope discrimination and photosynthesis, in: W.R. Briggs, R.L. Jones, V. Walbot (Eds.), Annual Review of Plant Physiology and Plant Molecular Biology, vol. 40, Annual Reviews Inc, Palo Alto, USA, 1989, pp. 503-537.

[45] D.L. Royer, S.L. Wing, D.J. Beerling, D.W. Jolley, P.L. Koch, L.J. Hickey, R.A. Berner, Paleobotanical evidence for near presentday levels of atmospheric $\mathrm{CO}_{2}$ during part of the Tertiary, Science 292 (2001) 2310-2313.

[46] H.W. Polley, H.B. Johnson, B.D. Marino, H.S. Mayeux, Increase in $\mathrm{C} 3$ plant water-use efficiency and biomass over the Glacial to present $\mathrm{CO}_{2}$ concentrations, Nature 361 (1993) 61-64.

[47] X. Feng, Trends in intrinsic water-use efficiency of natural trees for the past 100-200 years: a response to atmospheric $\mathrm{CO}_{2}$ concentration, Geochim. Cosmochim. Acta 63 (1999) 1891-1903.

[48] M. Saurer, R.T.W. Siegwolf, F.H. Schweingruber, Carbon isotope discrimination indicates improving water use efficiency of trees in northern Eurasia over the last 100 years, Glob. Chang. Biol. 10 (2004) 2109-2102.

[49] P.N. Pearson, M.R. Palmer, Atmospheric carbon dioxide concentrations over the past 60 million years, Nature 406 (2002) 695-699.

[50] R.V. Demicco, T.K. Lowenstein, L.A. Hardie, Atmospheric $p \mathrm{CO}_{2}$ since $60 \mathrm{Ma}$ from records of seawater $\mathrm{pH}$, calcium, and primary carbonate mineralogy, Geology 31 (2003) 793-796.

[51] T.K. Lowenstein, R.V. Demicco, Elevated Eocene atmospheric $\mathrm{CO}_{2}$ and its subsequent decline, Science 313 (2006) 1928.

[52] B.R.T. Simoneit, Cyclic terpenoids in the geosphere, in: R.B. Johns (Ed.), Biological Markers in the Sedimentary Record, Elsevier, Amsterdam, 1986, pp. 43-99.

[53] G. Lu, G. Keller, The Paleocene-Eocene transition in the Antarctic Indian Ocean: inference from planktic foraminifera, Mar. Micropaleontol. 21 (1993) 101-142.

[54] A. Pardo, G. Keller, E. Molina, J.I. Canudo, Planktic foraminiferal turnover across the Paleocene-Eocene transition at DSDP Site 401, Bay of Biscay, North Atlantic, Mar. Micropaleontol. 29 (1997) 129-158.

[55] G. Lu, T. Adate, G. Keller, N. Ortiz, Abrupt climatic, oceanographic and ecologic changes near the Paleocene-Eocene transition in the deep Tethys basin: the Alademilla section, southern Spain, Eclogae Geol. Helv. 91 (1998) 293-306.

[56] N.J. Shackleton, M.A. Hall, Carbon isotope data from Leg 74 sediments, in: T.C. Moore Jr., P.D. Rabinowitz, et al., (Eds.), Init. Repts. DSDP, vol. 74, U.S. Govt. Printing Office, Washington, 1984, pp. 613-619.

[57] T.J. Bralower, J.C. Zachos, E. Thomas, M. Parrow, C.K. Paull, D.C. Kelly, I. Premoli Silva, W.V. Sliter, K.C. Lohmann, Late Paleocene to Eocene paleoceanography of the equatorial Pacific Ocean: stable isotopes recorded at Ocean Drilling Program Site 865, Allison Guyot, Paleoceanography 10 (1995) 841-865.
[58] M.E. Katz, D.R. Katz, J.D. Wright, K.G. Miller, D.K. Pak, N.J. Shackleton, E. Thomas, Early Cenozoic benthic foraminiferal isotopes: species reliability and interspecies correction factors, Paleoceanography 18 (2003) 1024, doi:10.1029/2002PA000798.

[59] B.S. Cramer, M.-P. Aubry, K.G. Miller, R.K. Olsson, J.D. Wright, D.V. Kent, An exceptional chronologic, isotopic, and clay mineralogical record of the latest Paleocene thermal maximum, Bass River, NJ, ODP 174AX, Bull. Soc. Geol. Fr. 170 (1999) 883-897.

[60] F. Nunes, R.D. Norris, Abrupt reversal in ocean overturning during the Palaeocene/Eocene warm period, Nature 439 (2006) $60-63$.

[61] H.M. Stoll, Limited range of interspecific vital effects in coccolith stable isotopic records during the Paleocene-Eocene thermal maximum, Paleoceanography 20 (2005) PA1007, doi:10.1029/2004PA001046.

[62] C.J. Hollis, G.R. Dickens, B.D. Field, C.M. Jones, C.P. Strong, The Paleocene-Eocene transition at Mead Stream, New Zealand: a southern Pacific record of early Cenozoic global change, Palaeogeogr. Palaeoclimatol. Palaeoecol. 215 (2005) 313-343.

[63] B.S. Cramer, J.D. Wright, D.V. Kent, M.-P. Aubry, Orbital climate forcing of $\delta^{13} \mathrm{C}$ excursions in the late Paleocene-early Eocene (chrons C24n-C25n), Paleoceanography 18 (2003) 1097, doi:10.1029/2003PA000909.

[64] M.-P. Bolle, A. Pardo, K.U. Hinrichs, T. Adatte, K. von Salis, G. Keller, N. Muzylev, The Paleocene-Eocene transition in the marginal northeastern Tethys (Kazakhstan and Uzbekistan), Int. J. Earth Sci. 89 (2000) 390-414.

[65] R. Magioncalda, C. Dupuis, T. Smith, E. Steurbaut, P.D Gingerich, Paleocene-Eocene carbon isotope excursion in organic carbon and pedogenic carbonate: direct comparison in a continental stratigraphic section, Geology 32 (2004) 553-556.

[66] B. Schmitz, B. Peucker-Ehrenbrink, C. Heilmann-Clausen, G. Åberg, F. Asaro, C.-T.A. Lee, Basaltic explosive volcanism, but no comet impact, at the Paleocene-Eocene boundary: high-resolution chemical and isotopic records from Egypt, Spain and Denmark, Earth Planet. Sci. Lett. 225 (2004) 1-17.

[67] A. Sluijs, 2006. Global change during the Paleocene-Eocene thermal maximum. PhD Thesis, University of Utrecht, LPP Contributions Series No. 21, 228 pp.

[68] S. Bains, R.D. Norris, R.M. Corfield, G.J. Bowen, P.D. Gingerich, P.L. Koch, Marine-terrestrial linkages at the Paleocene-Eocene boundary, in: S.L. Wing, P.D. Gingrich, B. Schmitz, E. Thomas (Eds.), Causes and Consequences of Globally Warm Climates in the Early Paleogene, Geol. Soc. Am. Spec. Pap., vol. 369, 2003, pp. $1-11$

[69] B. Schmitz, V. Pujalte, Sea-level, humidity, and land-erosion records across the initial Eocene thermal maximum from a continental-marine transect in northern Spain, Geology 31 (2003) 689-692.

[70] M.E. Collinson, J.J. Hooker, D.R. Grocke, Cobham lignite bed and penecontemporaneous macrofloras of southern England: a record of vegetation and fire across the Paleocene-Eocene Thermal Maximum, in: S.L. Wing, P.D. Gingrich, B. Schmitz, E. Thomas (Eds.), Causes and Consequences of Globally Warm Climates in the Early Paleogene, Geol. Soc. Am. Spec. Pap., vol. 369, 2003, pp. 1-11. 